University of Nebraska - Lincoln

DigitalCommons@University of Nebraska - Lincoln

Agronomy \& Horticulture -- Faculty Publications

Agronomy and Horticulture Department

November 1998

\title{
Evaluation of Switchgrass Rhizosphere Microflora for Enhancing Seedling Yield and Nutrient Uptake
}

John J. Brejda

USDA-NRCS

Lowell E. Moser

University of Nebraska-Lincoln, Imoser1@unl.edu

Kenneth P. Vogel

University of Nebraska-Lincoln, kvogel1@unl.edu

Follow this and additional works at: https://digitalcommons.unl.edu/agronomyfacpub

Part of the Plant Sciences Commons

Brejda, John J.; Moser, Lowell E.; and Vogel, Kenneth P., "Evaluation of Switchgrass Rhizosphere Microflora for Enhancing Seedling Yield and Nutrient Uptake" (1998). Agronomy \& Horticulture -- Faculty Publications. 65.

https://digitalcommons.unl.edu/agronomyfacpub/65

This Article is brought to you for free and open access by the Agronomy and Horticulture Department at DigitalCommons@University of Nebraska - Lincoln. It has been accepted for inclusion in Agronomy \& Horticulture -Faculty Publications by an authorized administrator of DigitalCommons@University of Nebraska - Lincoln. 


\title{
Evaluation of Switchgrass Rhizosphere Microflora for Enhancing Seedling Yield and Nutrient Uptake
}

\author{
John J. Brejda, ${ }^{*}$ Lowell E. Moser, and Kenneth P. Vogel
}

\begin{abstract}
Many rhizosphere microorganisms enhance nutrient uptake and plant growth, but their effectiveness can vary with host species and with genotype within species. This study evaluated the effectiveness of rhizosphere microflora indigenous to the rhizosphere of switchgrass (Panicum virgatum L.) for enhancing seedling yield and nutrient uptake. Switchgrass roots and rhizosphere soil were collected from native prairies and seeded stands in Nebraska, Kansas, Iowa, Missouri, Virginia, and North Carolina. Seedlings of four switchgrass cultivars were inoculated with root fragments and rhizosphere soil from each collection, fertilized with a nutrient solution, and grown in steamed sand for 12 wk in a greenhouse. Seedlings inoculated with rhizosphere microflora produced up to 15 -fold greater shoot and root yields, and recovered up to 6 -fold more $N$ and 36 -fold more $P$ than seedlings inoculated with rhizosphere bacteria only. These responses were consistent for all four switchgrass cultivars and were probably due to arbuscular mycorrhizal fungi. Switchgrass rhizosphere populations were highly variable in their ability to recover $N$ and $P$ and stimulate seedling shoot and root yields. Seedlings inoculated with rhizosphere populations from seeded switchgrass stands averaged 1.5-fold greater shoot and root yields than seedlings inoculated with rhizosphere populations from native prairies. Rhizosphere populations that stimulated the greatest $\mathbf{N}$ uptake differed from populations that resulted in the greatest $P$ uptake. Highly effective microbial populations appear to develop in the rhizosphere of seeded switchgrass stands.
\end{abstract}

$\mathrm{O}$ VER THE PAST 20 YEARS, there has been a major increase in use of switchgrass (Panicum virgatum L.) for hay, summer grazing, soil conservation, and wildlife habitat (Moser and Vogel, 1995). Currently, there is interest in switchgrass as an energy crop (Moser and Vogel, 1995) because of its perennial nature, wide geographic distribution, high biomass yields, and ability to grow well in strongly acid soils with high exchangeable $\mathrm{Al}^{3+}$ concentrations (Balasko et al., 1984; Jung et al., 1988).

The profitability of switchgrass as a forage or biomass crop may be enhanced if yields can be increased with a concomitant decrease in chemical inputs, particularly $\mathrm{N}$ and $\mathrm{P}$ fertilizers. Research with other forage and grain crops indicates that rhizosphere microflora, particularly

J.J. Brejda, USDA-NRCS, Soil Quality Inst., 2150 Pammel Dr., Ames, IA 50011; L.E. Moser, Dep. of Agron., Univ. of Nebraska, 279 Plant Sci., P.O. Box 830915, Lincoln, NE 68583-0915; K.P. Vogel, USDAARS, 344 Keim Hall, Univ. of Nebraska, Lincoln, NE 68583-0915. The reported research is from a dissertation submitted by the senior author (John J. Brejda) in partial fulfillment of the requirements for a Ph.D. degree at the University of Nebraska. The research was funded in part by the U.S. Dep. of Energy's Biomass Fuels program via Oak Ridge Natl. Lab., USDA-ARS, and the University of Nebraska. Contract no. DE-A105-900R21954. Joint contribution of the USDAARS and the University of Nebraska Agric. Exp. Stn. as Journal Article 11919. Received 19 June 1997. *Corresponding author (brejda @nstl.gov).

Published in Agron. J. 90:753-758 (1998). arbuscular mycorrhizal fungi (AMF), can enhance $\mathrm{N}$ and P uptake (Abbott and Robson, 1984; Brejda et al., 1993; George et al., 1995), water uptake and drought tolerance (Safir et al., 1971; Allen, 1982; Sylvia and Williams, 1992), and protect against or enhance plant tolerance to rhizosphere pathogens (Paulitz and Linderman, 1991; Linderman, 1994). However, not all AMF populations and isolates are equally effective (Abbott and Robson, 1982; Medina et al., 1988; Hung et al., 1990), and some species can be parasitic on their host (Modjo and Hendrix, 1986; Hendrix et al., 1992; Johnson et al., 1992). The variation in effectiveness among different AMF indicate that, if AMF are to enhance nutrient uptake and yield of switchgrass, selection of more effective AMF is needed (Daft, 1992).

Other rhizosphere microorganisms influence the establishment and activity of AMF (Paulitz and Linderman, 1991; Linderman, 1992). Evaluation of plant growth and nutrient uptake responses to inoculation with pure mycorrhizal cultures in sterile soil may significantly overestimate AMF effects, because other soil microorganisms are not considered (Hetrick et al., 1988; Koide and $\mathrm{Li}, 1989$ ). Inoculum collected from switchgrass roots and rhizosphere soil in the field offers an advantage over pure cultures because it contains microbial populations already adapted to switchgrass under natural conditions. This suggests that, for some agriculturally based studies, rhizosphere inoculum may be most appropriate (Smith and Smith, 1981). However, there is no information on the effectiveness of different microbial populations indigenous to the rhizosphere of switchgrass. Our objective was to evaluate the effectiveness of different microflora populations indigenous to the rhizosphere of switchgrass plants for enhancing switchgrass seedling yield and nutrient uptake.

\section{MATERIALS AND METHODS}

Between 9 and 22 Oct. 1993, blocks ( 20 by 20 by $30 \mathrm{~cm}$ deep) of switchgrass roots and rhizosphere soil were collected directly beneath plant crowns in native prairies and seeded stands at 13 sites in six central and eastern states of the USA (Table 1). The 13 sites were chosen because they represent a diverse range in soil physical and chemical properties (Table 2). At each site, three plants located in the middle two-thirds of the stand were randomly selected for sampling. The blocks of soil containing switchgrass crown and root material, as collected in the field, were stored in a refrigerator at $4^{\circ} \mathrm{C}$ until they were processed.

Inoculum from each collection was prepared by compositing subsamples from the three plants sampled at each site and sifting the rhizosphere soil through a $2-\mathrm{mm}$ sieve to remove rocks and large litter fragments. All adhering root material was removed and the sieves were cleaned in distilled water and

Abbreviations: AMF, arbuscular mycorrhizal fungi. 
Table 1. State, county, switchgrass cultivar, and soil from which different rhizosphere populations were collected for evaluating their effectiveness with switchgrass.

\begin{tabular}{|c|c|c|c|}
\hline Location & County & $\begin{array}{c}\text { Switchgrass } \\
\text { cultivar }\end{array}$ & Soil \\
\hline \multicolumn{4}{|l|}{ lowa } \\
\hline Doolittle Prairie & Story & native & Kossuth silty clay loam (Typic Endoaquolls) \\
\hline Ames & Story & Cave-in-Rock & Sparta loamy fine sand (Entic Hapludolls) \\
\hline \multicolumn{4}{|r|}{ 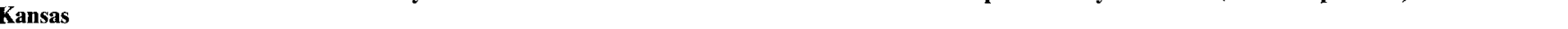 } \\
\hline Flinthills prairie & Pottawatomie & native & Pawnee clay loam (Aquertic Argiudolls) \\
\hline Manhattan & Pottawatomie & Blackwell & Wymore silt loam (Aquertic Argiudolls) \\
\hline \multicolumn{4}{|l|}{ Missouri } \\
\hline Kickapoo Prairie & Lawrence & native & Keeno cherty silt loam (Mollic Fragiudalfs) \\
\hline Elsberry & Lincoln & Cave-in-Rock & Kampville silt loam (Typic Endoaqualfs) \\
\hline Clifton Hill & Randolph & Blackwell & Piopolis silty clay loam (Typic Fluvaquents) \\
\hline \multicolumn{4}{|r|}{ A } \\
\hline Mead & Saunders & Pathfinder & Sharpsburg silty clay loam (Typic Argiudolls) \\
\hline Nine-Mile Prairie & Lancaster & native & Pawnee-Burchard clay loam (Aquertic-Typic Argiudolls) \\
\hline Sandhills prairie & Grant & native & Valentine fine sand (Typic Ustipsamments) \\
\hline \multicolumn{4}{|l|}{ North Carolina } \\
\hline \multirow{2}{*}{\multicolumn{4}{|c|}{ 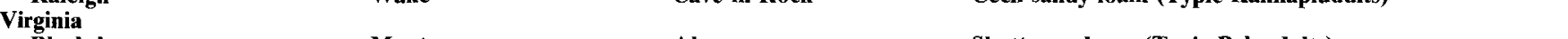 }} \\
\hline & & & \\
\hline Blacksburg & Montgomery & Alamo & Shottower loam (Typic Paleudults) \\
\hline Blacksburg & Montgomery & Cave-in-Rock & Shottower loam (Typic Paleudults) \\
\hline
\end{tabular}

allowed to dry between samples to avoid cross-contamination. Additional root material was clipped free from the rhizomes and crown, cut into $2-\mathrm{cm}$ pieces, and combined with the soil sievings.

Seed of four switchgrass cultivars were surface sterilized by soaking in a $0.07 \mathrm{M}$ solution of $\mathrm{NaOCl}$ for $15 \mathrm{~min}$, rinsed in distilled water, then germinated in vermiculite. The four cultivars evaluated were two lowland ecotypes, 'Alamo' and 'Kanlow', and two upland ecotypes, 'Cave-in-Rock' and 'Trailblazer'. Pots $(1.9 \mathrm{~L})$ containing steamed sand were inoculated with $55 \mathrm{~cm}^{3}$ of soil and roots from each collection. The inoculum was placed in a 5 -mm-thick band $2.5 \mathrm{~cm}$ below the soil surface, and three uniform seedlings of each cultivar were transplanted at 3 wk of age into each pot. All pots received 25 $\mathrm{mL}$ of a composite bacterial filtrate to equalize the background microflora (i.e., microflora apart from AMF and associated rhizosphere fungi). The filtrate was added because AMF live and function in the rhizosphere in association with other microorganisms, and their inclusion is needed to accurately assess the effect of AMF on plant growth and nutrient uptake. The filtrate was prepared by mixing together $55 \mathrm{~cm}^{3}$ of inoculant from each collection site, adding $6 \mathrm{~L}$ of water, and filtering the resultant slurry through a $20-\mu \mathrm{m}$ sieve with a peristaltic pump (Linderman and Hendrix, 1982). Switchgrass seedlings receiving only the composite bacterial filtrate were included as a control treatment. Plants were grown in a greenhouse supplemented with sodium-vapor lamps $(800 \mu \mathrm{mol}$ photon $\mathrm{m}^{-2} \mathrm{~s}^{-1}$ ) to provide a 14-h photoperiod. The greenhouse temperature was maintained between 16 and $32^{\circ} \mathrm{C}$. All pots were fertilized with 1 L of Clark's nutrient solution (Clark, 1982), which was modified to provide the equivalent of $4 \mathrm{mg} \mathrm{P} \mathrm{L}{ }^{-1}$ and $70 \mathrm{mg} \mathrm{N} \mathrm{L}^{-1}$. The nutrient solution was added in $100-\mathrm{mL}$ aliquots at weekly intervals for $10 \mathrm{wk}$.

Switchgrass shoots and roots were harvested after $12 \mathrm{wk}$,

Table 2. Physical and chemical properties of soils from which different rhizosphere populations were collected for evaluating their effectiveness with switchgrass. All soil test procedures follow Dahnke (1988).

\begin{tabular}{|c|c|c|c|c|c|c|c|c|c|c|c|}
\hline \multirow[b]{2}{*}{ Location } & \multicolumn{3}{|c|}{ Particle size $\dagger$} & \multirow[b]{2}{*}{$\mathbf{p H}+$} & \multirow{2}{*}{$\begin{array}{c}\text { Organic } \\
\text { C\$ }\end{array}$} & \multirow{2}{*}{$\begin{array}{c}\text { Total } \\
\text { NfI }\end{array}$} & \multirow{2}{*}{$\begin{array}{c}\text { Avail. } \\
\text { P\# }\end{array}$} & \multirow[b]{2}{*}{$\mathrm{CEC}+\mathrm{t}$} & \multicolumn{3}{|c|}{ Exchangeable $+\dagger$} \\
\hline & Sand & Silt & Clay & & & & & & $\mathrm{Ca}$ & $\mathbf{M g}$ & $\mathbf{K}$ \\
\hline & $\longrightarrow$ & $\%$ & - & & $\mathrm{g} \mathrm{kg}^{-1}$ & - & -1 & 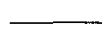 & cmol $_{c}$ & 1 & 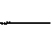 \\
\hline \multicolumn{12}{|c|}{ 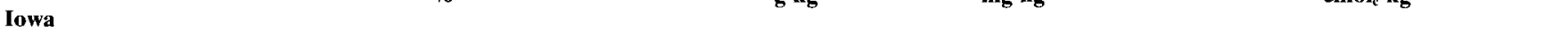 } \\
\hline Doolittle Prairie & 27 & 45 & 28 & 6.3 & 4.4 & 7.6 & 3 & 51 & 30.1 & 7.7 & 0.4 \\
\hline Ames & 85 & 8 & 7 & 6.7 & 1.4 & 2.5 & 147 & 11 & 6.4 & 1.4 & 0.6 \\
\hline \multicolumn{12}{|l|}{ Kansas } \\
\hline Flinthills Prairie & 15 & 71 & 14 & 6.5 & 4.4 & 6.9 & 13 & 35 & 19.7 & 4.1 & 1.2 \\
\hline Manhattan & 8 & 55 & 37 & 6.9 & 2.5 & 3.7 & 35 & 45 & 24.2 & 6.2 & 1.2 \\
\hline \multicolumn{12}{|l|}{ Missouri } \\
\hline Kickapoo Prairie & 11 & 73 & 16 & 5.6 & 3.3 & 5.3 & 4 & 23 & 9.8 & 0.8 & 0.2 \\
\hline Elsberry & 6 & 78 & 16 & 7.1 & 1.3 & 2.1 & 49 & 15 & 14.3 & 1.3 & 0.4 \\
\hline Clifton Hill & 8 & 80 & 12 & 7.0 & 2.0 & 3.4 & 54 & 32 & 21.7 & 3.3 & 0.4 \\
\hline \multicolumn{12}{|l|}{ Nebraska } \\
\hline Mead & 10 & 64 & 26 & 6.0 & 3.4 & 5.4 & 58 & 28 & 13.0 & 3.8 & 2.8 \\
\hline Nine-Mile Prairie & 29 & $\mathbf{5 1}$ & 20 & 6.0 & 2.8 & 4.6 & 9 & 25 & 11.8 & 3.0 & 1.0 \\
\hline Sandhills Prairie & 87 & 5 & 8 & 6.4 & 0.6 & 0.7 & 8 & 5 & 2.4 & 0.5 & 0.3 \\
\hline \multicolumn{12}{|l|}{ North Carolina } \\
\hline \multirow{2}{*}{\multicolumn{12}{|c|}{ Virginia }} \\
\hline & & & & & & & & & & & \\
\hline Blacksburg (Alamo) & 36 & 47 & 17 & 5.1 & 1.5 & 2.7 & 92 & 10 & 1.0 & 0.6 & 0.5 \\
\hline Blacksburg (CIR f) & 45 & 39 & 16 & 5.5 & 1.4 & 2.4 & 86 & 11 & 1.4 & 0.6 & 0.3 \\
\hline
\end{tabular}

$\dagger$ Bouyoucos hydrometer method.

1:1 soil:water.

§ LECO Cr12 carbon analyzer.

II LECO FP428 nitrogen analyzer.

\# Bray and Kurtz No. 1 with ascorbic acid modification.

$\dagger 1 \mathrm{M} \mathrm{NH}_{4} \mathrm{OAc}$ extract at pH 7.0 and determined using atomic absorption.

$\ddagger$ CIR, Cave-in-Rock. 
Table 3. Analysis of variance and mean squares for four switchgrass cultivars inoculated with 13 different rhizosphere populations, or a bacterial filtrate control in two separate experiments. $t$

\begin{tabular}{|c|c|c|c|c|c|c|}
\hline Source of variation & df & Shoot wt. & Root wt. & N uptake & P uptake & Colonization \\
\hline Experiment (Exp) & 1 & $3.4 * *$ & $32.7 * *$ & $13470 * *$ & $32.6^{* * *}$ & $\ddagger$ \\
\hline Inoculant (Inoc) & 13 & $33.7^{* *}$ & 23.3** & $4370^{* * *}$ & $68.3 * *$ & $2887 * *$ \\
\hline Switchgrass cultivar $\S$ & $\mathbf{3}$ & $19.1^{*}$ & 1.6 & $975 *$ & 2.6 & $402 *$ \\
\hline lowland vs. upland & (1) & $56.6^{* *}$ & 1.7 & $2888 * *$ & 0.7 & $\mathbf{4 3 7}$ \\
\hline Alamo vs. Kanlow & (1) & 0.0 & 1.7 & 3 & 6.7 & 8.6 \\
\hline CIR vs. Trailblazer & (1) & 0.7 & 1.5 & 31 & 0.5 & $761^{*}$ \\
\hline $\operatorname{Exp} \times \operatorname{Inoc}$ & 13 & $2.7^{* *}$ & $2.5 * *$ & $282 * *$ & $6.4^{* * *}$ & \\
\hline Exp $\times$ Cultivar & 3 & 1.5 & 0.9 & 20 & $6.8 * *$ & \\
\hline Inoc $\times$ Cultivar & 39 & 1.4 & 1.2 & 190 & 3.2 & 231 \\
\hline Exp $\times$ Inoc $\times$ Cultivar & 39 & 0.7 & 0.6 & 113 & 2.3 & \\
\hline Error & 336 & 0.8 & 0.6 & 108 & 1.7 & 159 \\
\hline
\end{tabular}

*,** Significant at the 0.05 and 0.01 probability levels, respectively.

$\dagger$ Experiments were analyzed as a random effect, and inoculants and switchgrass cultivars were fixed effects.

\& Percentage colonization was determined in the second experiment only.

$\$$ Alamo and Kanlow are lowland ecotypes; Cave-in-Rock (CIR) and Trailblazer are upland ecotypes.

dried separately at $60^{\circ} \mathrm{C}$ for $48 \mathrm{~h}$ in a forced-air oven, and weighed. The shoot and root materials were ground separately in a Wiley mill to pass a 1-mm screen and analyzed for total $\mathrm{N}$ and $\mathrm{P}$ concentrations. Total $\mathrm{N}$ was determined using the Kjeldahl procedure, and $\mathbf{P}$ by $\mathrm{X}$-ray fluorescence (Knudsen et al., 1981). Nitrogen and $P$ uptake was calculated by multiplying shoot and root $\mathrm{N}$ and $\mathrm{P}$ concentrations by shoot and root dry weights. The experiment was repeated with a second field collection of switchgrass roots and rhizosphere soil, collected between 26 April and 15 May 1994 from the same sites sampled previously, and 18-d-old seedlings using the same procedures described above. In the second experiment, a root subsample was taken directly from the zone of inoculation, cleared in $\mathrm{KOH}\left(25 \mathrm{~g} \mathrm{~L}^{-1}\right)$, and stained with trypan blue $\left(0.5 \mathrm{~g} \mathrm{~L}^{-1}\right)$ in acid glycerol using the procedure of Koske and Gemma (1989). Percentage mycorrhizal colonization was determined by examining 100 root intercepts at $25 \times$ magnification using the gridline intersect method of Giovannetti and Mosse (1980). The first experiment was planted on 26 January and harvested on 20 April; the second experiment was planted on 23 May and harvested on 15 August.

Both experiments were replicated four times and analyzed as a factorial arrangement of 2 experiments, 4 switchgrass cultivars, and 14 microbial treatments (including the bacterial filtrate control). The analysis of variance involved a mixed model in which the experiments were treated as random effects and the switchgrass cultivars and microbial treatments as fixed effects. Microbial treatment means were compared using Fisher's protected LSD test at the 0.05 significance level. Switchgrass cultivar differences were analyzed using preplanned orthogonal contrasts to compare (i) the upland vs. lowland ecotypes and (ii) the two cultivars within each ecotype.

\section{RESULTS}

\section{Shoot and Root Yields}

In both experiments, inoculation of switchgrass seedlings with different rhizosphere populations increased shoot and root weights up to 16 -fold compared with seedlings receiving only the bacterial filtrate control. Although there was a significant $(P<0.01)$ experiment $\times$

Table 4. Mean values (pooled across switchgrass cultivars) of shoot weights, root weights, $N$ uptake, and $P$ uptake for each of the inoculants in the two experiments. Percentage colonization was measured in the second experiment only.

\begin{tabular}{|c|c|c|c|c|c|c|c|c|c|}
\hline \multirow{2}{*}{$\begin{array}{l}\text { Inoculum } \\
\text { collection } \\
\text { site }\end{array}$} & \multicolumn{4}{|c|}{ 1st Exp. } & \multicolumn{5}{|c|}{ 2nd Exp. } \\
\hline & $\begin{array}{c}\text { Shoot } \\
\text { wt. }\end{array}$ & $\begin{array}{c}\text { Root } \\
\text { wt. }\end{array}$ & $\begin{array}{c}\text { N } \\
\text { uptake }\end{array}$ & $\begin{array}{c}\text { P } \\
\text { uptake }\end{array}$ & $\begin{array}{c}\text { Shoot } \\
\text { wt. }\end{array}$ & $\begin{array}{c}\text { Root } \\
\text { wt. }\end{array}$ & $\begin{array}{c}\mathbf{N} \\
\text { uptake }\end{array}$ & $\begin{array}{c}\text { P } \\
\text { uptake }\end{array}$ & Colonization \\
\hline & $\longrightarrow \mathrm{g}$ & 1 & $\longrightarrow \mathbf{m}$ & $-1-$ & $\longrightarrow \mathrm{E}$ & 1 & $\longrightarrow \mathbf{m}$ & ${ }^{-1}$ & $\%$ \\
\hline \multicolumn{10}{|l|}{ Iowa } \\
\hline Doolittle & 1.9 & 1.2 & 48 & 2.0 & 2.1 & 1.6 & 34 & 2.4 & 1 \\
\hline Ames & 3.0 & 2.6 & 64 & 4.0 & 3.6 & 3.3 & 47 & 5.1 & 3 \\
\hline \multicolumn{10}{|l|}{ Kansas } \\
\hline Flinthills & 2.5 & 1.6 & 50 & 2.8 & 2.6 & 2.2 & 46 & 3.2 & 13 \\
\hline Manhattan & 3.5 & 2.6 & 63 & 4.2 & 4.3 & 3.7 & 52 & 5.4 & 33 \\
\hline \multicolumn{10}{|l|}{ Missouri } \\
\hline Kickapoo & 1.5 & 1.2 & 44 & 1.9 & 1.9 & 1.7 & 33 & 2.2 & 6 \\
\hline Elsberry & 3.6 & 2.6 & 57 & 3.7 & 2.8 & 2.7 & 47 & 3.8 & 4 \\
\hline Clifton Hill & 4.0 & 3.0 & 57 & 5.6 & 4.3 & 3.9 & 53 & 7.8 & 44 \\
\hline \multicolumn{10}{|l|}{ Nebraska } \\
\hline Mead & 3.2 & 2.2 & 64 & 4.0 & 4.6 & 3.9 & 55 & 4.8 & 18 \\
\hline Nine-Mile Prairie & 2.7 & 2.5 & 65 & 3.1 & 2.0 & 1.9 & 39 & 2.7 & 1 \\
\hline Sandhills Prairie & 3.0 & 2.1 & 53 & 3.4 & 3.3 & 2.8 & 46 & 4.1 & 22 \\
\hline \multicolumn{10}{|l|}{ North Carolina } \\
\hline Raleigh & 3.1 & 2.6 & 59 & 3.5 & 3.7 & 3.3 & 48 & 5.6 & 17 \\
\hline \multicolumn{10}{|l|}{ Virginia } \\
\hline Blacksburg (Alamo) & 2.7 & 2.1 & 48 & 3.6 & 2.3 & 2.1 & 40 & 2.7 & 3 \\
\hline Blacksburg (CIR $\dagger$ ) & 3.0 & 1.9 & 51 & 3.8 & 2.8 & 2.6 & 43 & 3.6 & 3 \\
\hline Bacterial filtrate & $\mathbf{0 . 3}$ & 0.2 & 11 & $\mathbf{0 . 3}$ & 0.3 & 0.3 & 9 & 0.2 & $\mathbf{0}$ \\
\hline SE & 0.4 & 0.3 & 5 & 0.5 & 0.5 & 0.4 & 5 & 0.8 & 6 \\
\hline LSD (0.05) & 1.0 & 0.9 & 15 & 1.5 & 1.4 & 1.2 & 13 & 2.1 & 17 \\
\hline
\end{tabular}

$\dagger$ CIR, Cave-in-Rock. 
Table 5. Mean values (pooled across inoculants) of shoot weights, root weights, $\mathbf{N}$ uptake, and $P$ uptake for each of the switchgrass cultivars in the two experiments.

\begin{tabular}{|c|c|c|c|c|c|c|c|c|c|}
\hline \multirow[b]{2}{*}{ Cultivar } & \multicolumn{4}{|c|}{ Ist Exp. } & \multicolumn{4}{|c|}{ 2nd Exp. } & \multirow[b]{2}{*}{ Colonization } \\
\hline & $\begin{array}{c}\text { Shoot } \\
\text { wt. }\end{array}$ & $\begin{array}{c}\text { Root } \\
\text { wt. }\end{array}$ & $\begin{array}{c}\mathbf{N} \\
\text { uptake }\end{array}$ & $\underset{\text { uptake }}{\mathbf{P}}$ & $\begin{array}{c}\text { Shoot } \\
\text { wt. }\end{array}$ & $\begin{array}{c}\text { Root } \\
\text { wt. }\end{array}$ & $\begin{array}{c}\mathbf{N} \\
\text { uptake }\end{array}$ & $\underset{\text { uptake }}{\mathbf{P}}$ & \\
\hline & \multicolumn{2}{|c|}{$\longrightarrow \mathrm{g}$ pot $^{-1} \longrightarrow$} & \multicolumn{2}{|c|}{$=\mathrm{mg} \mathrm{pot}{ }^{-1} \longrightarrow$} & \multicolumn{2}{|c|}{$-\mathrm{g} \mathrm{pot}^{-1} \longrightarrow$} & \multicolumn{2}{|c|}{$\longrightarrow \mathrm{mg} \mathrm{pot}^{-1} \longrightarrow$} & $\%$ \\
\hline Alamo & 3.0 & 2.1 & 56 & 3.3 & 3.3 & 2.8 & 44 & 4.2 & 10.8 \\
\hline Kanlow & 3.2 & 2.0 & 56 & 3.4 & 3.2 & 2.5 & 45 & 3.3 & 10.3 \\
\hline Cave-in-Rock & 2.3 & 2.0 & 51 & 3.3 & 2.7 & 2.7 & 40 & 4.1 & 15.9 \\
\hline Trailblazer & 2.4 & 2.0 & 50 & 3.5 & 2.4 & 2.3 & 39 & 3.7 & 10.7 \\
\hline SE & 0.4 & 0.3 & 5 & 0.5 & 0.5 & 0.4 & 5 & 0.8 & 6.3 \\
\hline
\end{tabular}

microbial inoculant interaction for both shoot and root weights (Table 3 ), the magnitude of the interaction was small and resulted from small changes in the response observed with some of the microbial inoculants.

Consistent patterns were evident in both experiments with respect to the effects of the different rhizosphere populations on shoot and root weights. Seedlings with the greatest shoot and root weights were inoculated with rhizosphere microflora from seeded switchgrass stands near Clifton Hill, MO, Manhattan, KS, and Mead, NE (Table 4). In contrast, seedlings with the lowest shoot and root weights were inoculated with rhizosphere microflora from native switchgrass plants at Kickapoo Prairie in Missouri and Doolittle Prairie in Iowa (Table 4).

Switchgrass shoot weights, but not root weights, were greater with the two lowland ecotypes, Alamo and Kanlow, than with the two upland ecotypes, Cave-in-Rock and Trailblazer (Table 5); however, there was no significant difference in shoot weights between the two cultivars within each ecotype. Interactions between switchgrass cultivars and microbial inoculants or experiments were not significant for shoot and root weights (Table 3).

Shoot and root weights were positively correlated with the $\mathrm{pH}$ of the soil used as inoculum (Table 6). Root weights, but not shoot weights, were also positively correlated with available $\mathrm{P}$, and negatively correlated with organic $\mathrm{C}$ and total $\mathrm{N}$ concentrations in the soil used as inoculum.

\section{Nitrogen and Phosphorus Uptake}

In both experiments, inoculation of switchgrass seedlings with different rhizosphere populations increased $\mathrm{N}$ uptake as much as 6-fold, and $\mathrm{P}$ uptake up to 37 -fold compared with seedlings receiving only the bacterial filtrate control. As with shoot and root weights, there was a significant $(P<0.01)$ experiment $\times$ microbial inoculant interaction for $\mathrm{N}$ and $\mathrm{P}$ uptake (Table 3), but the magnitude of the interaction was small and resulted from small changes in the amount of $\mathrm{N}$ and $\mathrm{P}$ taken by seedlings inoculated with some of the microbial populations.

Consistent patterns were evident in both experiments with respect to the effects of the different rhizosphere populations on $\mathrm{N}$ and $\mathrm{P}$ uptake. The rhizosphere microflora that produced high $\mathrm{N}$ and $\mathrm{P}$ uptake were collected from seeded stands near Mead, NE, and Manhattan, KS (Table 4). Seedlings inoculated with rhizosphere microflora from seeded stands at Clifton Hill, MO, and Ames, IA, also had high $\mathrm{P}$ uptake, but not high $\mathrm{N}$ uptake. In contrast, seedlings with the lowest $\mathrm{N}$ and $\mathrm{P}$ uptake were inoculated with rhizosphere microflora from native switchgrass plants at Kickapoo Prairie in Missouri, Doolittle Prairie in Iowa, Nine-Mile Prairie in Nebraska, and a seeded stand of Alamo near Blacksburg, VA (Table 4).

Uptake of N, but not of P, was significantly greater with the two lowland ecotypes, Alamo and Kanlow, than with the two upland ecotypes, Cave-in-Rock and Trailblazer (Tables 3 and 5). However, there was no significant difference in $\mathrm{N}$ uptake between the two cultivars within each ecotype. Interactions between switchgrass cultivars and microbial inoculants or experiments were not significant for $\mathrm{N}$ and $\mathrm{P}$ uptake (Table 3 ).

Nitrogen and $P$ uptake were positively correlated with the $\mathrm{pH}$ of the soil used as inoculum (Table 6). In addition, $\mathrm{N}$ uptake, was positively correlated with exchangeable $\mathrm{K}$ in the soil used as inoculum.

\section{Percentage Colonization}

Mycorrhizal colonization of switchgrass seedlings varied significantly between the different rhizosphere populations (Table 3). Percentage colonization was signifi-

Table 6. Correlation $(r)$ between shoot weight, root weight, $N$ uptake, and $P$ uptake (pooled across switchgrass cultivars) with soil properties at the 13 inoculum collection sites.

\begin{tabular}{|c|c|c|c|c|c|}
\hline Soil property & Shoot wt. & Root wt. & N uptake & P uptake & Colonization \\
\hline Sand & 0.01 & 0.08 & 0.04 & 0.04 & -0.19 \\
\hline Silt & -0.03 & -0.08 & -0.08 & -0.01 & 0.18 \\
\hline Clay & 0.07 & -0.01 & 0.13 & $-\mathbf{0 . 1 1}$ & 0.12 \\
\hline pH & $\mathbf{0 . 5 8} \dagger$ & $0.58 \dagger$ & $0.57 \dagger$ & $\mathbf{0 . 5 7} \dagger$ & $\mathbf{0 . 5 2} \dagger$ \\
\hline Organic C & $-\mathbf{0 . 3 9}$ & -0.48 & -0.26 & -0.42 & -0.11 \\
\hline Total N & -0.43 & $-0.51 \dagger$ & -0.31 & -0.44 & -0.16 \\
\hline Avail. P & $\mathbf{0 . 3 9}$ & $0.50 \dagger$ & $\mathbf{0 . 3 7}$ & 0.44 & -0.05 \\
\hline CEC & -0.05 & -0.15 & -0.02 & -0.07 & 0.25 \\
\hline Exch. Ca & 0.07 & $-\mathbf{0 . 0 3}$ & 0.07 & 0.06 & 0.32 \\
\hline Exch. Mg & 0.06 & -0.05 & 0.12 & -0.01 & 0.23 \\
\hline Exch. K & 0.38 & 0.30 & $0.57 \dagger$ & 0.14 & 0.17 \\
\hline
\end{tabular}

$\dagger$ Significant at $\alpha=\mathbf{0 . 1 0}$. 
cantly $(P<0.01)$ correlated with shoot weight $(r=$ $0.77)$, root weight $(r=0.74), \mathrm{N}$ uptake $(r=0.70)$, and $\mathrm{P}$ uptake $(r=0.82)$. No mycorrhizal colonization was detected in switchgrass seedlings inoculated with only the bacterial filtrate in either experiment.

Mycorrhizal colonization was significantly greater with Cave-in-Rock switchgrass than with the other three cultivars (Table 5). The switchgrass cultivar $\times$ microbial population interaction was not significant. Mycorrhizal colonization was significantly correlated with the $\mathrm{pH}$ of the soil used as inoculum (Table 6); percentage colonization was not significantly correlated with any other property of the inoculant soil.

\section{DISCUSSION}

Several groups of microorganisms may be responsible for the large increases in shoot and root weights and in $\mathrm{N}$ and $\mathrm{P}$ uptake following inoculation of seedlings with rhizosphere microflora from established switchgrass stands. These groups include plant growth promoting rhizosphere bacteria, AMF, and nonmycorrhizal fungi such as saprophytes or pathogens. Studies using an inoculation method similar to our method have shown that rhizosphere bacteria can have a positive (Murdoch et al., 1967), negative (Wilson et al., 1988; Hetrick et al., 1988; Hetrick et al., 1990; Koide and Li, 1989), or no effect (Manjunath and Bagyaraj, 1981) on plant growth. However, enhanced plant growth resulting from inoculation with rhizosphere bacteria alone was consistently and significantly smaller than the effect of AMF on plant growth. The poor growth of switchgrass seedlings inoculated with only the bacterial filtrate in this study, consistent with results from the above-mentioned studies, indicates that rhizosphere bacteria probably were not responsible for the large increases in nutrient uptake and shoot and root yields observed on this study.

Changes in $\mathrm{N}$ and $\mathrm{P}$ availability through organic matter mineralization or nutrient immobilization by saprophytic bacteria and fungi could have affected seedling growth. However, the small and generally nonsignificant correlations between shoot yields or nutrient uptake, and organic $\mathrm{C}$, total $\mathrm{N}$, and available $\mathrm{P}$ in the soil used as inoculum suggest that the amounts of $\mathrm{N}$ and $\mathrm{P}$ in these soils did not have a strong influence on seedling yield or nutrient uptake. In addition, spores or oomycetes of saprophytic or pathogenic fungi were not observed in or around the roots that were stained and scored for percentage AMF colonization. Rather, the high correlations between percentage colonization and shoot and root weights and $\mathrm{N}$ and $\mathrm{P}$ uptake observed in the second experiment suggest that AMF are responsible for the responses observed in this study.

The most effective rhizosphere populations for increasing shoot and root weights and $\mathrm{N}$ and $\mathrm{P}$ uptake came from seeded switchgrass stands; rhizosphere populations from native prairies were relatively less effective. The greater effectiveness of AMF populations associated with long-term seeded switchgrass stands is in contrast to several studies indicating that, under monocropping systems, less effective or even parasitic AMF populations can develop (Modjo and Hendrix, 1986; Hendrix et al., 1992; Johnson et al., 1992). However, all of these studies involved annual crops, and there is limited information on changes in the species composition and effectiveness of AMF in the rhizosphere of perennial plants. Our results suggest that AMF and associated rhizosphere microflora that are highly effective in enhancing seedling growth and nutrient uptake develop in the rhizosphere of switchgrass monocultures. The effectiveness of different rhizosphere populations in improving growth and nutrient uptake of inoculated switchgrass seedlings under field conditions needs to be evaluated.

\section{REFERENCES}

Abbott, L.K., and A.D. Robson. 1982. The role of vesicular arbuscular mycorrhizal fungi in agriculture and the selection of fungi for inoculation. Aust. J. Agric. Res. 33:389-408.

Abbott, L.K., and A.D. Robson. 1984. The effects of mycorrhizae on plant growth. p. 113-130. In C.L. Powell and D.J. Bagyaraj (ed.) VA mycorrhiza. CRC Press, Inc., Boca Raton, FL.

Allen, M.F. 1982. Influence of vesicular-arbuscular mycorrhizae on water movement through Bouteloua gracilis (H.B.K.) Lag ex Steud. New Phytol. 91:191-196.

Balasko, J.A., D.M. Burner, and W.V. Thayne. 1984. Yield and quality of switchgrass grown without soil amendments. Agron. J. 76: 204-208.

Brejda, J.J., D.H. Yocom, L.E. Moser, and S.S. Waller. 1993. Dependence of 3 Nebraska Sandhills warm-season grasses on vesiculararbuscular mycorrhizae. J. Range Manage. 46:14-20.

Clark, R.B. 1982. Nutrient solution growth of sorghum and corn in mineral nutrition studies. J. Plant Nutr. 5:1039-1057.

Daft, M.J. 1992. Use of VA mycorrhizas in agriculture: Problems and prospects. p. 198-201. In Read et al. (ed.) Mycorrhizas in ecosystems. CAB Int., Wallingford, UK.

Dahnke, W.C. (ed.). 1988. Recommended chemical soil test procedures for the North Central region. N. Central Reg. Publ. 221 (revised). N. Dak. Agric. Exp. Stn. Bull. 499.

George, E., H. Marschner, and I. Jakobsen. 1995. Role of arbuscular mycorrhizal fungi in uptake of phosphorus and nitrogen from soil. Crit. Rev. Biotechnol. 15:257-270.

Giovannetti, M., and B. Mosse. 1980. An evaluation of techniques for measuring vesicular arbuscular mycorrhizal infection in roots. New Phytol. 84:489-500.

Hendrix, J.W., K.J. Jones, and W.C. Nesmith. 1992. Control of pathogenic mycorrhizal fungi in maintenance of soil productivity by crop rotation. J. Prod. Agric. 5:383-386.

Hetrick, B.A.D., G.T. Wilson, D.G. Kitt, and A.P. Schwab. 1988. Effects of soil microorganisms on mycorrhizal contribution to growth of big bluestem grass in non-sterile soil. Soil Biol. Biochem. 20:501-507.

Hetrick, B.A.D., G.T. Wilson, and T.C. Todd. 1990. Differential responses of $\mathrm{C}_{3}$ and $\mathrm{C}_{4}$ grasses to mycorrhizal symbiosis, phosphorus fertilization, and soil microorganisms. Can. J. Bot. 68:461-467.

Hung, L.L., D.M. Sylvia, and D.M. O'Keefe. 1990. Isolate selection and phosphorus interaction of vesicular-arbuscular mycorrhizal fungi in biomass crops. Soil Sci. Soc. Am. J. 54:762-768.

Johnson, N.C., P.J. Copeland, R.K. Crookston, and F.L. Pfleger. 1992. Mycorrhizae: Possible explanation for yield decline with continuous corn and soybean. Agron. J. 84:387-390.

Jung, G.A., J.A. Shaffer, and W.L. Stout. 1988. Switchgrass and big bluestem responses to amendments on strongly acid soil. Agron. J. 80:669-676.

Knudsen, D., R.B. Clark, J.L. Denning, and P.A. Pier. 1981. Plant analysis of trace elements by X-ray. J. Plant Nutr. 3:61-75.

Koide, R.T., and M. Li. 1989. Appropriate controls for vesiculararbuscular mycorrhiza research. New Phytol. 111:35-44.

Koske, R.E., and J.N. Gemma. 1989. A modified procedure for staining roots to detect VA mycorrhizas. Mycol. Res. 92:486-488.

Linderman, R.G. 1992. Vesicular-arbuscular mycorrhizae and soil microbial interactions. p. 45-70. In G.J. Bethlenfalvay and R.G. Linderman (ed.) Mycorrhizae in sustainable agriculture. ASA Spec. Publ. 54. ASA, CSSA, and SSSA, Madison, WI.

Linderman, R.G. 1994. Role of VAM fungi in biocontrol. p. 1-25. In 
F.L. Pfleger and R.G. Linderman (ed.) Mycorrhizae and plant health. Am. Phytopathol. Soc., St. Paul, MN.

Linderman, R.G., and J.W. Hendrix. 1982. Evaluation of plant response to colonization by vesicular-arbuscular mycorrhizal fungi: A. Host variables. p. 69-76. In N.C. Schenck (ed.) Methods and principles of mycorrhizal research. Am. Phytopathol. Soc., St. Paul, MN.

Manjunath, A., and D.J. Bagyaraj. 1981. Components of VA mycorrhizal inoculum and their effects on growth of onion. New Phytol. 87:355-361.

Medina, O.A., D.M. Sylvia, and A.E. Kretschmer. 1988. Response of siratro to vesicular-arbuscular fungi: 1 . Selection of effective vesicular-arbuscular fungi in amended soil. Soil Sci. Soc. Am. J. 52:416-419.

Modjo, H.S., and J.W. Hendrix. 1986. The mycorrhizal fungus Glomus macrocarpum as a cause of tobacco stunt disease. Phytopathology 76:688-691.

Moser, L.E., and K.P. Vogel. 1995. Switchgrass, big bluestem, and indiangrass. p. 409-420. In R.F Barnes et al. (ed.) Forages: An introduction to grassland agriculture. Vol. 1. 5th ed. Iowa State Univ. Press, Ames.
Murdoch, C.L., J.A. Jackobs, and J.W. Gerdemann. 1967. Utilization of phosphorus sources of different availability by mycorrhizal and non-mycorrhizal maize. Plant Soil 27:329-334.

Paulitz, T.C., and R.G. Linderman. 1991. Mycorrhizal interactions with soil microorganisms. p. 77-129. In D.K. Arora et al. (ed.) Handbook of applied mycology. Vol. 1. Soil and plants. Marcel Dekker, New York.

Safir, G.R., J.S. Boyer, and J.W. Gerdemann. 1971. Mycorrhizal enhancement of water transport in soybeans. Science (Washington, DC) 172:581-583.

Smith, F.A., and S.E. Smith. 1981. Mycorrhizal infection and growth of Trifolium subterraneum: Comparison of natural and artificial inocula. New Phytol. 88:311-325.

Sylvia, D.M., and S.E. Williams. 1992. Vesicular-arbuscular mycorrhizae and environmental stress. p. 101-124. In G.J. Bethlenfalvay and R.G. Linderman (ed.) Mycorrhizae in sustainable agriculture. ASA Spec. Publ. 54. ASA, CSSA, and SSSA, Madison, WI.

Wilson, G.W.T., D.A.D. Hetrick, and D.G. Kitt. 1988. Suppression of mycorrhizal growth response of big bluestem by non-sterile soil. Mycologia 80:338-343. 